\title{
SUITABILITY OF ICE FOR AIRCRAFT LANDINGS
}

\author{
Robert P. Sharp
}

Abstract--The thickness of ice required for alrcraft landings on skis can be calculated from the following formulas:

$$
s_{r}=(15 / 4) \sqrt{W_{t}} ; \quad s_{\ell}=(27 / 8) \sqrt{W_{t}} ; s_{s}=(27 / 4) \sqrt{W_{t}}
$$

$S_{r}$ is the thiclness in inches for river ice, $s_{f}$ for lake ice, and $s_{S}$ for old sea ice. $W_{t}$ is the weight of the plane in tons. These formulas allow for the static weight of the plane and 1 ts dynamic impact at the time of landing. The thicknesses calculated are for ice formed at or below $16^{\circ} \mathbf{F}$. For ice formed at higher temperatures the thicknesses must be increased by about 25 per cent. $S_{\mathbb{S}}$ is for old sea ice. Young sea 1 ce 15 weaker and must be about three times as thick as river 1ce. Planes on wheels require about 20 per cent greater thickness than calculated from the above formulas. Ice is stronger at lower temperatures, and its strength increases about four times between $23^{\circ} \mathrm{F}$ and $-76^{\circ} \mathrm{F}$. Salt, alr bubbles, included vegetation, cracks, and heavy snow cover all make ice weaker. Ice also experiences elastic fatigue under constant heavy use and must be rested frequently.

Freeze-up usually takes place many days or even several weeks after the mean air temperature falls below freezing. After the water temperature reaches freezing, the rate of formation and growth of lce may be predicted from a curve of degree days of frost or calculated by formula.

Salinity retards freezing by lowering both the freezing point and the maximumdensity temperature. Currents, waves, and snow cover also retard the growth of ice, but under proper conditions wind can be an asset. Ice continues to increase in thickness well beyond the perlod of minimum air temperature. Thereafter, it maintains its maximum thickness for a short time before showing a rapid decrease just prior to breakup. Ice deteriorates considerably in spring, and its strength decreases more rapidly than its thickness. Thls is particularly true of lake ice which "candles," Salty ice honeycombs extensively.

The surface of most frozen fresh-water bodies is usually sultable for landings, but sea ice is oftell rough and broken. However, many successful landings and take-offs have been made from the ice pack, and a sultable place can frequently be found. Firm, wind-packed snow can have a beartng strength of 100 to $200 \mathrm{lb} / \mathrm{ln}^{2}$, but wind-swept surfaces are often rough owing to drifts and sastrugi.

Introduction--The following is strictly an office compilation from a variety of sources. It contains no original material and is not based on the experiments or fleld observations of the compiler, who is no cryologist. These data were assembled during World War II and issued as a preliminary report of the Arctic, Desert, and Tropic Branch of the Army Air Forces Center. The report has been cleared for publication by the United States War Department and is reproduced here in essentlally its original form.

The major aim is to provide information pertinent to some aspects of aircraft operations on ice, particularly landings. The formation of ice, some of its physical characteristics, and other factors affecting its suitability for alrcraft operations are consider ed briefly. These matters are not treated from a geographical standpoint, although an attempt is made to provide some means by which approximate thicknesses of ice in remote regions can be predicted.

Problems of iee in relation to a1rcraft landings have been most fully studied by the Russians. Digests of this Russian information and considerable data from other sources have been made available through the cooperation of A. D. Bajkov, formerly of the Air Technical Service Command, United States Army A1r Forces. Much of this compilation should be credited to Bajkov.

Formation of ice--It is now generally concluded that $\mathrm{H}_{2} \mathrm{O}$ molecules are at least temporarily bonded together in twos and threes [see "References" at end of paper, DORSEY, 1940]. The single molecule, $\mathrm{H}_{2} \mathrm{O}$ or hydrol, is water vapor; the double molecule, $\left(\mathrm{H}_{2} \mathrm{O}\right)_{2}$ or dihydrol, is water in the 
liquld form; and the aggregate of three moleculor, $\left(\mathrm{H}_{2} \mathrm{O}\right)_{3}$ or trifydrol, 1s 1ce. With increasing tempreratur: dhydrol (water) tends to change to hydrol (water vapor) and with decreasing tempera. ture to trihydrol (Ice). The stgnificant relation here is that dihydrol (water) contains trihydrol (lco) In sislution. At $100^{\circ} \mathrm{F}$ water is satd to contain 16 por cent ice in solution, and this rises to 37 per cent approachlng the Ircezing point [BARNES, 1028], although these figures may not be untverially accepted [DORSEX, 1040]. At the freezing point water becomes a saturated solution, and Ice lis prectpltated. Super-cooled water behaves essentially like any supersaturated solution.

D1swolved walts lowor the freezing point and produce a slgnificant difference in the freezing temperature of fresh and sea water as shown in Table 1 . Average sea water has a salinity of 35 parts per thousand and freezes at $28^{\circ} 6 \mathrm{~F}$ [WORDIE and ROBERTS, 1944].

Table 1- - Salinity and freezing polnts

\begin{tabular}{|c|c|c|}
\hline Saldnity & Froezing & polntsi \\
\hline part:s/1000) & ${ }^{\circ} \mathrm{C}$ & ${ }^{*} \mathrm{~F}$ \\
\hline 0 & 0 & 32 \\
\hline is & -0.3 & 31.5 \\
\hline I1) & -0.5 & 31.1 \\
\hline 15 & -0.8 & 30.6 \\
\hline 20 & -1.1 & 30 \\
\hline 24.905 & $=1.332$ & 29.61 \\
\hline 25 & -1.35 & 20.57 \\
\hline 30 & $-1,0$ & 20.12 \\
\hline 35 & -1.0 & 28.58 \\
\hline 40 & -2.2 & 28.0 \\
\hline
\end{tabular}

Salinity also affects the freezing point through its $\mathrm{in}$ fluence on density [WORDIE and ROBERTS, 1044]. Fresh water reaches its maximum density at $30^{\circ} 2 \mathrm{~F}$, so density currents do not clevelop with further cooling, and only the surllelal layer need be cooled to the freezing point before a layer of loe can form. Conduction complicates this simplifled picture to some degreo. Water with a salinity of $5 \% / 00$ has $1 \mathrm{t}$ H preatest density at $37: 2 \mathrm{~F}$, so the entlre body of water must be cooled to that temperature before density currents cense. The maximum-density temperature and the freezlng temperature approach each other as salinity increaser. They colnclde when the sallnity is $24.065 \% 00$. 'Thisi moans that with a sallnity of $24 ; 695 / 00$ or more density currents operate clear down to the freezing point, and the entyo water body must be cooled to this temperature before a layer of 1 ce can form on the surface. The rapldity of cesoling and the total drop in temperature are often so proat and densty currents so slow that leo probably doses lorm in nature before the temperature of

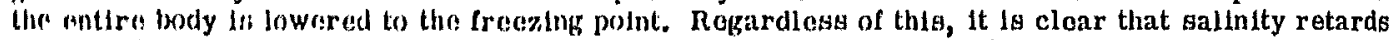
trasglng by lesworlng the maximum-dentily temporature as well as by lowering the froezing point.

II at II lost from water chlefly by conduction, convection, radiation, and evaporation, and any factores affecting these procosses are signifleant in tho formatlon and growth of lce.

Zentth anple of the esus, and therefore lattlude, aro Important becauso with a low sun water burfiswes reflect is comfilderible part of the solar radtation. The following information and figures arr frum IDEVIK [194A]. In owrthern latitudes Ifi winter tho hent recelved from direct solar radiathon ind from diffused radlation ls far bolow the amount of hoat lost from the water. Loss of heat by Intrared ridlatlon les nonrly three thmes as great wtth a clear sky as with a complete cloud cover. Hout losin by conveetion lis controlled by temperaturo difference botween the water surface and alr atid in lucreatied by wine. At $14^{\circ} \mathrm{F}$ alr temporature, water tomperature $32^{\circ} \mathrm{F}$, and no wind, the heat

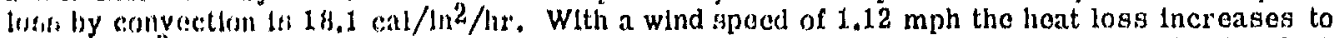
$74.2 \mathrm{col} / \mathrm{In}^{2} / \mathrm{hr}$. Heat lofit by evaporation depends largely upon vapor presgure gradient and wind. At alr tomperature $14^{\circ} \mathrm{F}$, waler temperature $32^{\circ} \mathrm{F}$, a vapor pressure $2.6 \mathrm{~mm}$ mercury, and no wind, the lomb by evitporation $1410.0 \mathrm{cal} / \mathrm{In} 2 / \mathrm{hr}$. Under the samo conditlons but with a wind speed of $1.12 \mathrm{mph}$ it $\mathrm{ts} 49.7 \mathrm{cal} / \mathrm{ln} 2 / \mathrm{hr}$ [DEVIK, 1844]. Although wind alds cooling by Increasing heat loss throuph convection and evaporation, it retards freezing by disturbing the surface of the water. However, freezing during a calm following a windy period is benefted by the cooling produced by the wind. Once a layer of lee is formed, wind can aid its growth by blowing away the snow that lalls on its surface or by packing the snow more firmly and thereby reducing its power of insulatlon,

At $14^{\circ} \mathrm{F}$, vapor pressure of $2.6 \mathrm{~mm}$ mercury, zero wind velocity, no cloud caver, sun altitude $5^{\circ}$, and water temperature $32^{\circ} \mathrm{F}$, the total heat lost exceeds the heat gained by $94.8 \mathrm{cal} / \mathrm{ln} 2 / \mathrm{hr}$. with all conditions the same except for a wind velocity of $1.12 \mathrm{mph}$ and cloudiness ten, the heat lost exceeds the heat galned by $150 \mathrm{cal} / \mathrm{ln}^{2} / \mathrm{hr}$. In the ftrst case ice will be produced at 0.079 in $/ \mathrm{hr}$ and in the second at $0.126 \mathrm{in} / \mathrm{hr}$ [DEVIK, 1944].

Snow falling into water has a cooling effect, but this $151 \mathrm{kkely}$ to be relatively insignificant except when the water is already close to freezing. However, at this temperature snowflakes ald freezing both by cooling and by providing nuclei around which ice crystals develop. 
Water cools slowly and its surface temperature always lags behind the rise and fall of the mean sir temperature. In the Murmansk-White Sea area, rivers usually freeze about three weeks after the mean air temperature falls below $32^{\circ} \mathrm{F}$. This is probably representative for many similar regions. Lakes usually freeze a little earlier. Inland waters contalning much vegetation do not freeze as quickly as clear water, and swift currents in rivers obvlously retard freezing and may even prevent it.

The following factors facllitate the formation of ice in the sea: (1) Freshening of the water by precipitation, rivers, or melting of ice; (2) hindrance of wave and other water motion; (3) presence of floating chunks of old ice which cool the water and reduce wave motion; (4) shallow water; (5) lack of currents; and (6) lack of storms [SMITH, 1932, and TRANSEHE, 1928].

Freezing of sea water is first indicated by a greasy or olly appearance and shortly thereafter small spicules and plates called "frazll 1ce" become visible. Frazll ice increases untll the water is covered with a mush of crystals called "slush" or "sludge.". This material gradually agglomerates into roughly circular flat masses called "pancakes," and the pancakes are eventually cemented together to form "floes" and "sheets" [WORDIE and ROBERTS, 1944]. Ice formed on bodles of fresh water is usually relatively clear and smooth, but in the sea such ice forms only in protected coves and narrow lanes or leads cutting through the ice pack. In fast-running streams spongy accumulations of fraztl tce on the bottom and along the shores are usually the first phase in the freeze-up [DEVIK, 1944].

Growth and thickness of 1ce--Heat loss at the rate of $120 \mathrm{cal} / \mathrm{in}^{2} / \mathrm{hr}$ causes ice to form at the rate of $0.1 \mathrm{in} / \mathrm{hr}$ if the water temperature is $32^{\circ} \mathrm{F}$ [DEVIK, 1944]. Newly formed 1ce may grow to a thickness of four or flve inches in the first 48 hours. Thereafter growth is slower. Once a solid

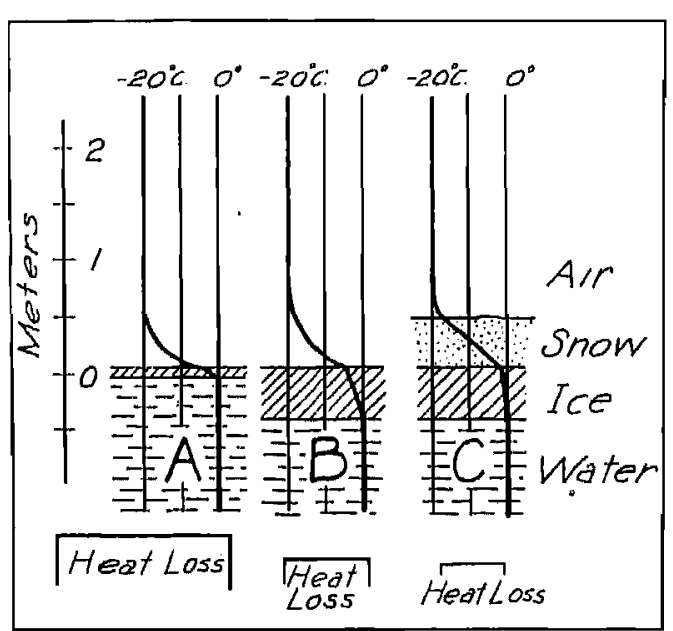

Fig, 1--Thermal gradient and heat loss through: $A$, thin ice; $B$, thick ice; $C$, thick ice and snow [after Devik] layer of ice is formed, further growth depends chlefly upon conduction of heat through the ice to the colder air above, and this in turn depends upon the steepness of the temperature gradient. The effect of an increasing ice thickness and a snow cover upon heat loss ts illustrated in the following diagram, Figure 1. Evaporation from the ice surface and radiation, which takes place only when the ice is clear and its surface free of snow, play a small part. Convection currents in the water usually retard the growth of ice. Sea ice seldom grows to a thickness greater than flve to seven feet in the first year. If unbroken through the second winter, the thickness may reach seven to eight feet at the most. Ice in the far northern rivers and lakes can grow to a thickness of six to eight feet in a single season. With rare exceptions this fresh-water ice disappears entirely in summer, but sea ice is perennial in the Polar Basin. Perennial sea ice may grow in thickness during the summer by the following means. Snow on the surface melts, and the water runs down through cracks and holes to form a layer of fresh water under the ice. Since the temperature of the underlying salt water is usually lower than the freezing point of fresh water, a layer of fresh-water ice is formed on the bottom of the sea ice [WORDIE and ROBERTS, 1944].

Ice in the Polar Basin is seldom less than $3-1 / 2$ to $4-1 / 2$ feet thick, and Nansen [ZUBOV, 1940] reports a maximum thickness of $13 \mathrm{ft}$ ten inches produced by about four years of normal growth. Much greater thicknesses can be formed by rafting, tidal overflow, other types of flooding, spray, and splashing. Ice in hummocks and pressure ridges sometimes attalns a thickness of 50 to 100 feet.

The rate of growth of fresh-water 1ce may be calculated by Formula (1) [BARNES, 1928]:

$$
\mathrm{t}=(\mathrm{LSE} / \mathrm{K} \theta)(1+\mathrm{E} / 2) \ldots \ldots \ldots \ldots \ldots \ldots
$$

in which $t$ is the time in seconds for the ice sheet to attain a thickness $E$ in centimeters; $L$ is the heat of fusion, $80 \mathrm{cal} / \mathrm{gm} ; \mathrm{S}$ is the density of ice, $0.9166 ; \mathrm{K}$ is the conductivity of 1ce, $0.0057 \mathrm{cal}$ per degree difference of temperature $\mathrm{C}$, per $\mathrm{cm}^{2}$, per sec; and $\theta$ is the difference in temperature, $\mathrm{C}$, between the underside of the ice sheet, assumed $0^{\circ} \mathrm{C}$, and the air temperature. 
Table 2 provlde!l axamples of the results obtalned from (1) with the above assumptions. Thlcknetbirs!s are converted from centlmeters to inchos and temporatures from Centigrade to Farenheit.

Table 2--Rate of growth of an lce layer

\begin{tabular}{c|c|c|c|c}
\multirow{2}{*}{$\begin{array}{c}\text { Thicknoss } \\
\text { of lce }\end{array}$} & \multicolumn{4}{|c}{ Temperatures } \\
\cline { 2 - 5 } & $14^{\circ} \mathrm{F}$ & $-4^{\circ} \mathrm{F}$ & $-22^{\circ} \mathrm{F}$ & $-40^{\circ} \mathrm{F}$ \\
\hline In & day & day & day & day \\
1 & 0.086 & 0.043 & 0.029 & 0.021 \\
6 & 1.95 & 0.98 & 0.65 & 0.49 \\
10 & 5.19 & 2.60 & 1.73 & 1.29 \\
12 & 7.38 & 3.60 & 2.46 & 1.85 \\
24 & 28.80 & 14.30 & 9.53 & 7.15 \\
36 & 63.69 & 31.85 & 21.23 & 15.92 \\
\hline
\end{tabular}

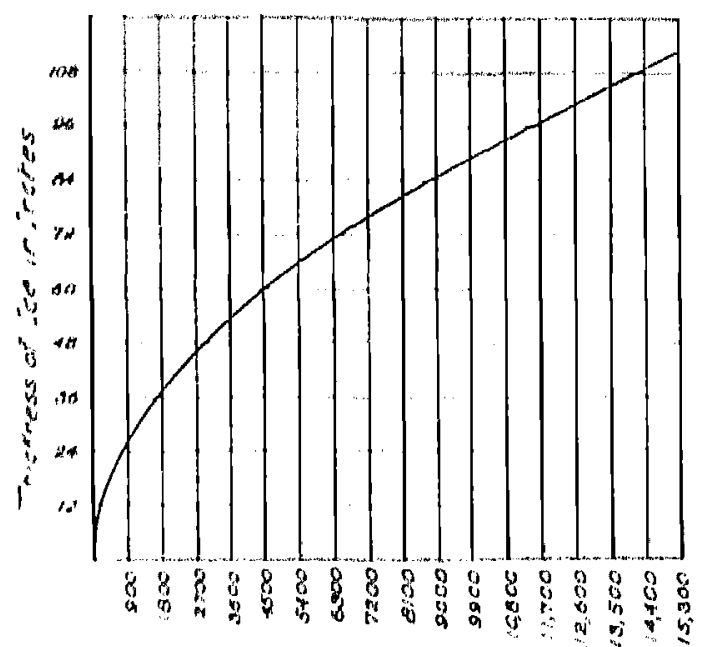

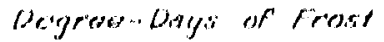

Plr. 2.-. Rates of prowth of lea
The approximate thickness of lce may be prodicted lrom the curve of Figure 2 if the tomperatures at a spectfled locallty aro known. Even if exact temperatures are not avallable estimates can probably be made from a general knuwledge of weather conditions in the repion. In calculating the degree days of frost it must bo remember ed that $0^{\circ} \mathrm{F}$ is $32^{\circ}$ of frost. Furthermore, it $1 \mathrm{~s}$ better to add up the mean numbor of degreos of frost for each day or group of days having about the same mean degrees of frost than to make a single calculation using a large number of days and a mean figure for the degress of frost for the entire pertod. Days on which the temperature was below freezing for only part of the 24 hours can be ignored unless exceptionally numcrous, and excessive refinemonts in calculation of degree days of frost are nether nocessary nor justifted. Examples of calculations of degree days of frost follow. Assume a specified day had elght hours below freszing, and the mean temperature for those olght hours was $23^{\circ} \mathrm{F}$. The degree days of frost for that day aro $8 / 24 \times 9=3$. Suppose the next disy had lempuritures bolow froczlng for the ontire 24 hours, and the mean temperature was $20^{\circ} \mathrm{F}$. che deyree day: of frost for this day are 12, If the next ten days had approximately uniform mean tomperature, swy - 20" $\mathrm{r}$, and all hourg were bolow freezing, the degree days of frost for the ten dayt are 520. The total degree days of frost for the 12-day period described above would be 535 . A plitnce at Fligur: 2 shows that the curve permits considerable approximation in calculating degree dayf af frost without serfously affecting the final results. Obviously other factors such as wind, snow, and currents introduce complications difficult to evaluate and not allowed for in the graph. The liswermost end of the curve is none too rellable because freezing weather may exist for a number of days before ice starts to form. Once a layer of ice has begun to form, the curve is much more reliable unless thawing occurs.

Weokly measurements of Ice thickness in far northern harbors [BERNIER, 1910, and LOW, 1900] five curves which risc stendlly for two-thirds to three-fourths of the total period, flatten aff brlefly, and then drop abruptly just prior to breakup.

Physical nature and structures of ice--Ice is reported to precipitate as a collold from water super-cooled by as little as a few thousandths of a degree [BARNES, 1928]. The colloidal particles agglomerate and form plate- and spicule-shaped crystals [BARNES, 1928]. In calm fresh water, lee forms long hexagonal prismatic crystals arranged perpendicular to the water surface. If undisturbed these crystals grow into long pencils equal to the thickness of the ice layer, Freshened sea fce may also develop this structure, but young sea ice is sald to consist of an uppermost onehalf-inch layer of thin horizontal ice plates about the size of a fingernall with the ice beneath consisting of vertical prismatic crystals [WORDIE and ROBERTS, 1944]. Some young fresh-water Ice has a simllar arrangement. Ice crystals have gliding planes parallel to the base, but experi- 
ments show that aggregates of parallel prismatic crystals may yield more readily along the prismatlc face than along the base [MATSUYAMA, 1920].

New sea tce usually contains five to $15 \%$ salt. Ice formed slowly or in calm weather has less salt than ice formed rapidly or in rough weather. For example, young sea ice formed at $14^{\circ} \mathrm{F}$ has four to $6^{\circ} / 00$ salt, but that formed at $-40^{\circ} \mathrm{F}$ has ten to $15^{\circ} / 00$ [WORDIE and ROBERTS, 1944]. As sea water freezes, a network of fresh-water crystals develops, forming pockets which contain salt water. The crystals grow at the expense of this brine, which becomes progressively heavier and more concentrated. Depending upon the temperature, this brine may or may not freeze, and even if it does freeze it thaws readily with rising temperature. Its high salinity and welght enable it to melt a path gradually downward through the ice, and the flushing-out process is facilitated by rising temperature and thawing. In this manner salt-water ice becomes fresh and changes from greasy, streaky and opaque to more or less granular, brittle, and clear, as well as increasing in strength. Hummocking hastens the freshening process by providing cracks for drainage and by lifting the ice above its surroundings so that the brine flushes out more ensily.

Arctic sea Ice contains three to ten per cent alr, and fresh-water or brackish-water 1ce contalns about two per cent air. Small a1r bubbles are spherical, but many of the larger ones are elongated vertically into thread-like tubes. Different horizontal layers of ice may contain differing amounts of alr. Usually lce formed quickly or in rough weather contains more alr than that formed slowly or in quiet weather [BAJKOV].

Several high-pressure forms of ice are known from laboratory studies, but none has been found in nature [DORSEY, 1940, and SELIGMAN, 1836].

Strength of lce--The strength of lce is dependent upon a wide variety of conditions, some of which will be treated following a simplified consideration of the thickness of ice required for aircraft landings.

Several empirical rules concerning the thickness of tce able to support various loads have been developed. Unfortunately, these do not usually specify the nature of the 1ce, its conditions of formation, or 1ts environment. A familiar example of such rules are those stating that two inches of ice is considered safe for infantry, four inches for cavalry or light guns, six inches for heavy field guns, and elght inches for loads on sledges weighing not over 1000 lbs per square foot. Blind application of such empirical rules may lead to trouble. The Russians have done considerable work with the loading strength of lce and landings of aircraft thereon. Much of the following material has been derived fróm their reports [BAJKOV, MOSKATOV, 1938 a and b].

If some data are already available on the various loads borne by Ice of known character and thickness, they can be extrapolated, for the required safe thickness of ice is directly proportional to the square root of its tolerable load. Thus, if it is known in a spectflc locality that a certain thickness of $1 \mathrm{ce}, \mathrm{s}_{1}$, will bear a load, $\mathrm{L}_{1}$, then by simple proportion the thickness, $s_{2}$, needed to carry a load, $\mathrm{L}_{2}$, can be calculated as:

$$
\mathrm{S}_{2}{ }^{2} / \mathrm{S}_{1}{ }^{2}=\mathrm{L}_{2} / \mathrm{L}_{1} \text { or } \mathrm{S}_{2}=\sqrt{\mathrm{L}_{2} \mathrm{~S}_{1}^{2} / \mathrm{L}_{1}} \ldots \ldots \ldots \ldots \ldots
$$

For aircraft landings, both the static load of the plane and the dynamic load or impact at time of landing must be considered. The usual Russian practice is to take six times the static weight of the plane as safely equivalent to these loads combined. Therefore, to obtain the thickness of ice necessary for a plane landing from data for static loads the formula will be

$$
S_{2}=\sqrt{\left(S_{1}^{2} \times 6 W_{p}\right) / L_{1}}
$$

in which $W_{p}$ is the static weight of the plane. If the thickness of ice for landing of a plane of spectfied weight is already known, the formula can be used in the form first given.

It is known that fresh-water ice is about three times as strong as salt-water ice. This introduces a factor $\sqrt{3}$ in the formula for converting data from fresh-water ice to salt-water ice, thus:

$$
s_{s}=1.732 \sqrt{\left(s_{f w}{ }^{2} \times L_{2}\right) / L_{1}} \ldots \ldots \ldots \text { (4) }
$$

in which $S_{S}=$ thickness of sea ice; $S_{f w}=$ thickness of fresh-water ice.

From various accumulated data the Russians have developed the following simplified formulas for landings of alr craft with skis: 


$$
\left.\begin{array}{l}
S_{r}=(15 / 4) \sqrt{w_{t}} \\
S_{\ell}=(27 / 8) \sqrt{w_{t}} \\
S_{S}=(27 / 4) \sqrt{w_{t}}
\end{array}\right\} .
$$

$S_{r}$ is the thickness of river ice, $S_{\ell}$ of lake ice, and $S_{S}$ of sea ice, in inches, and $w_{t}$ is the weight of the plane in tons. These formulas apply to ice formed at or below $16^{\circ} \mathrm{F}$. For ice formed at higher temperatures the thicknesses should be about 25 per cent greater. Lake ice is generally about ten per cent stronger than river ice. Probably no airplane, even the lightest, should attempt to land on fresh-water ice less than six inches thick. The $S_{S}$ in the third formula above is for old sea ice, which is stronger than young sea ice. The required thickness of young sea ice is about three times that of river ice.

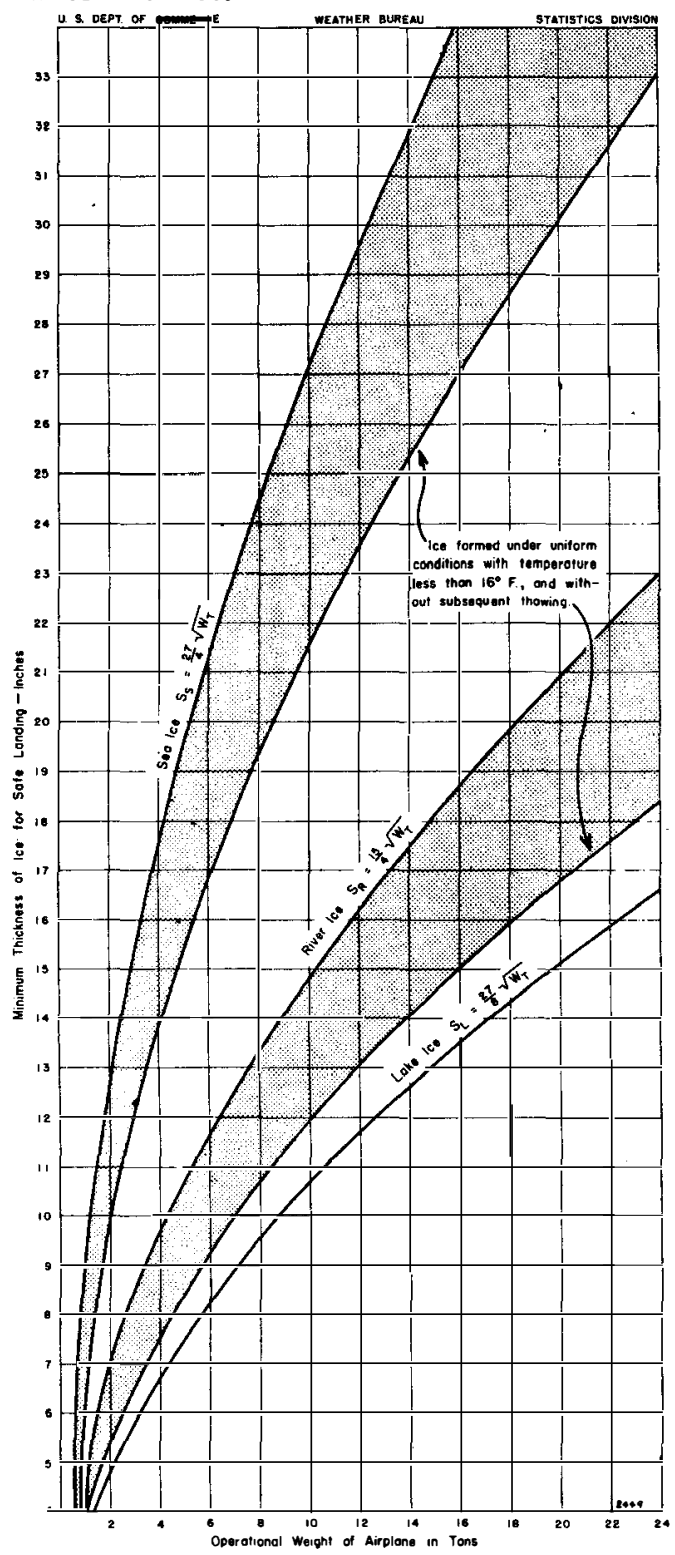

Fig. 3--Minimum thickness of ice required for safe landings of aircraft on skis [after U. S. Weather Bureau]
The curves of Figure 3 have been constructe from the above formulas. For planes on wheels the ice thickness should be about 20 per cent greater. Allowances must be made for major cracks and other structural weaknesses.

The above data can be checked by the following theoretical calculations. It is known that a roughly circular area with a radius of about 30 meters bears the load of an object the size of an aircraft on the ice surface. On this basis Formula (6) may be used to determine the ice thickness required for a specified load:

$$
\mathrm{S}_{\mathrm{b}}=\left(18 \mathrm{KP} / \pi \mathrm{T}^{2}\right)\left(1-2 \mathrm{r}_{\mathrm{o}} / 3 \mathrm{r}\right) \ldots \ldots
$$

in which $S_{b}$ is the maximum breaking strength taken as $30 \mathrm{~kg} / \mathrm{cm}^{2}$ for fresh-water ice and 15 $\mathrm{kg} / \mathrm{cm}^{2}$ for salt-water ice; $K$ is a coefficient taken at $0.5 ; \mathrm{r}$ is the radius of a circular plate bearing the load taken at 30 meters; $r_{0}$ is the radius of circle upon which the load is concentrated--this is the size of the skis calculated as a circular area; $P$ is weight of the plane in $\mathrm{kg}$; and $T$ is necessary thickness of ice for safe landing, in centimeters.

Substituting the figures for river ice and rearranging we get

$$
\mathrm{T}_{\mathrm{r}}=\sqrt{3 \times 0.5\left[1-\left(2 \mathrm{r}_{\mathrm{o}} / 3 \mathrm{r}\right)\right] 6 \mathrm{P} / 3.14(30)} .
$$

This can be simplified, since $\left(1-2 r_{0} / 3 r\right)$ can be taken as unity. Then $T_{r}=0.31 \sqrt{\mathrm{P}}$. This gives thickness of river ice in $\mathrm{cm}$ with weight of plane in $\mathrm{kg}$, or $\mathrm{T}_{\mathrm{r}}=3.68 \sqrt{\mathrm{P}}$ gives thickness in inches with weight in tons. This is very close to the $S_{r}=15 / 4 \sqrt{W_{t}}$ given above, as $15 / 4=$ 3.75. Thus the theoretical and analogical methods check.

Salt makes ice plastic and weak [BRUCE, 1911], and sea ice becomes stronger as it freshens in the manner previously described. Newly formed sea ice less than six inches thick may bend under the weight of a man [BROWN, 1927]. It is probably unsafe for heavily loaded sledges and obviously unsuited for plane landings. Most sea ice has a breaking strength of ten to 15 $\mathrm{kg} / \mathrm{cm}^{2}$ in contrast to the $30 \mathrm{~kg} / \mathrm{cm}^{2}$ of freshwater ice [MOSKATOV, $1938 \mathrm{a}$ and b]. The crushing strength of ice ranges from 327 to $1000 \mathrm{lbs} / \mathrm{in}^{2}$ and increases as the temperature 
falls, Increasing four times between $23^{\circ} \mathrm{F}$ and $-76^{\circ} \mathrm{F}$ [BAJKOV]. Falling temperature, however, leads to contraction and cracking of 1ce and may weaken an lce layer even though water rises in the cracks and seals them. The tensil strength of ice is about one-third its crushing strength. Vegetation Included within the ice makes it weaker.

Ice covered with a thick layer of snow is weaker because it is warmer, and ice becomes much weaker in spring for various reasons treated in more detall elsewhere. An abundance of parallel thread-like alr bubbles in some ice decreases its strength considerably.

Ice shows the phenomenon of elastic fatigue and will bend or sag under continual stress [HAYES, 1937]. Constant travel of heavy loads over ice causes fatigue and further weakens it by opening and widening cracks. A fast-traveling plane on take-off or landing sends a wave through the ice before it and is followed by another wave. These waves cause fatigue and set up stresses which can be released by boring small holes through the ice [HAYES, 1937]. Heavily used runways on ice should be given frequent rest periods to allow recovery from fatigue and sealing of cracks.

Role of snow--Snow is important with regard to alrcraft landings on frozen water bodles because more often than not it constitutes the surficial material. Since it is an excellent insulator it also exerts considerable influence on the rate at which ice forms and the thickness attained.

A common assumption in the North is that heavy snow in the fall means a rapid break-up in spring.

Snow constitutes an extra load on the ice and keeps it warmer, therefore weaker. These disadvantages are partly offset if the snow is well packed. Hard-packed snow does not retard the growth of ice nearly so much as loose snow and has a considerable bearing strength of its own. Wind-packed snow without benefit of thaw may have a bearing strength between 100 and $200 \mathrm{lbs} / \mathrm{In}^{2}$ [BAJKOV]. Firm, wind-packed snow of this type is found chiefly in unforested northern areas where strong winds prevall, In such areas the snow tends to be firmly packed throughout, not just on the surface. In other regtons a surficial crust on soft fluffy snow may give a misleading impression of the strength of a snow cover.

The snow on areas of ice to be used frequently for landings should be scraped or rolled. Scraping allows a greater thickness of tce to develop, but rolling is preferred in some quarters, posstbly because of the bearing strength of firmly-packed snow, or because of unevenness in the underlying Ice. In one instance the ice under an area scraped six days before was 16 inches thick and that under a nearby uncleared area was only 12 inches [HAYES, 1937]. Air temperatures during this pertod are not known. Another good reason for clearing snow from the ice is the prevention of slush formed if water gains access to the snow through cracks or by other means. Several inches of lce are destroyed by formation of the slush, which refreezes slowly even at air temperatures well below zero [HAYES, 1937]. If the snow cover is very thick, water forced up through holes and cracks in the ice forms a layer of slush with the lowermost snow which is entirely hidden by the overlying unaffected snow [DEPARTMENT OF NATIONAL DEFENSE, 1944]. The potential dangers of this situation are obvious. A snow cover on ice constitutes a further hazard by hiding weak spots which might otherwise be apparent from the air. Weak spots in the Ice on Inland water bodies can sometimes be ldentified by animal tracks leading up to but not across them. In any case the snow should be cleared from an area larger than that actually needed for operation, so that cracks and holes in the nearby ice have a chance to freeze. Snow should not be piled close to the runway, as it weakens the ice. If the surface of the ice beneath the snow ls rough, scraping is obviously out of the question.

Even loose powdery snow changes progressively throughout the season without benefit of thawing. It becomes more granular and better packed. The increase in grain size is due to condensation of moisture from the atmosphere and the transfer of vapor from the vicinity of small grains to larger grains where ice is deposited. This takes place because the vapor pressure around ice grains is inversely proportional to the radius of curvature and is higher around small grains than large ones [SELIGMAN, 1936]. The surface of snow in wind-swept regions, although firm, is often rough in detall, owing to the formation of drifts, barchans, and sastrugi. Sastrugi are small ridges of hard-packed snow up to two feet high and ten to 15 feet long arranged parallel to the prevalling wind direction. They are capable of upsetting almost any plane on wheels or skis. Barchans are similar ridges lying transverse to the wind.

Nature of 1ce surface--The rough surface on sea tce more often limits its use for aircraft operations than thickness or strength. The surface of river and lake ice is usually smoother. Much sea ice is broken, rafted, pushed into hummocks and cracked by tides, winds, and currents 
In such a way as, to make it wholly unsulted for alrcraft operations. The open lee pack of summer rontilting, of sepauate lee trapmonts ls obviously unsulted for alrcraft landings unless some of the fleme are axceptlomally larpe. In winter much of this open pack refreezes with a surface that ts too Inuph for atreraft lianding! untll covered with snow. This ls true in many of the flords of East Gromland [WA'TKINS, 1932]. 'Tlwe closed pack may be sultable both winter and summer, 'although oni pelaur ther hati nstimated that fully 90 per cent of the Arctic ice pack is unsultable for alrcraft landimis [DYRD, 1029]. However, there have been many success[ul landings and take-offs from thr Arctle flack, and sultible areas; can wisually be found [MOSKATOV, 1938 b, and ZUBOV, 1940]. Alomy, low lageon-fringed Aretic shorelines, like the north coast of Alaska, large areas of smooth flat tee are avallable for whter landlngs [WILKINS, 1928 a and b].

Sprlngtimo melting catn make an tee surfact vory rough. Salty sea tce becomes soft and honeycombed tu silring even though the alr temperature remalns bolow freezing [DEPARTMENT OF NATIONAL, DHFENSE, 1944]. It li; advisable to avold areas of lce covered with melt water because the burface benesth l:i likely to be pltted and rough. Howover, it is true that molt water standing on for in an Indeatlon of the :soundessist of that tee. As thawling progresses the water disappears into

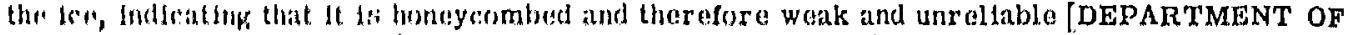
NATIONAL DEFENSL, 104d|. After the molt witer runs off, the dee surface is dry, white, soft, and

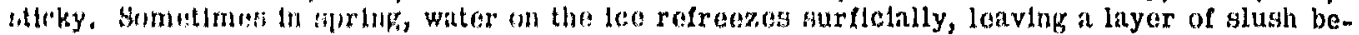

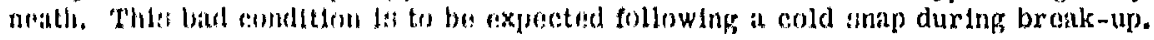

Frowih water, partlendarly in laker:t, freozes to a firm smoth surface, but rlvors may have

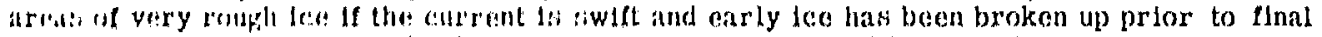

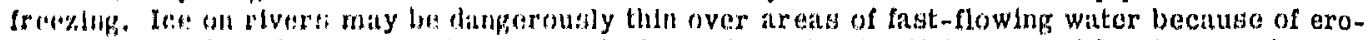

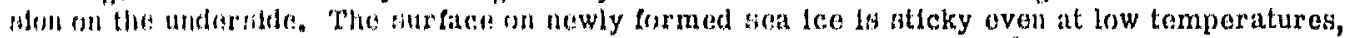

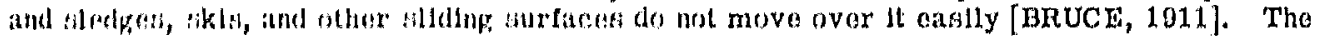

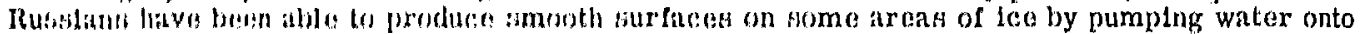

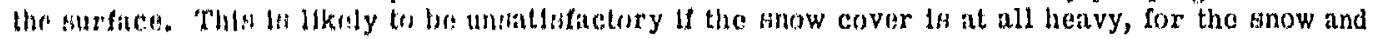

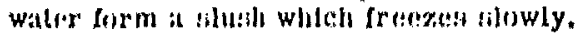

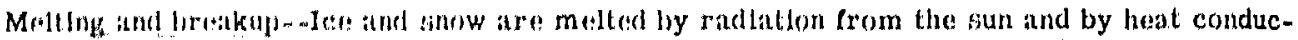
low from the atr, rockes, and witur. Another less commonly rocogndzed mode of melting $1 \mathrm{~s}$ by condentatlon of warm mentst alr. Thus can be an Important factor, for the motsture so condonsed malts ap to 7-1/2 tlmots the won wotght in snew [LIGHT, 1941].

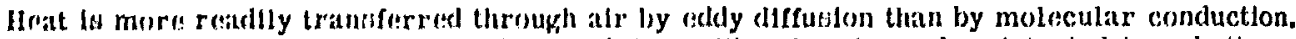
Thus, molting tet lekely to lue greater' with a whod than with calm alr, and molst wind lis a better mateng apent that dry wind of thes sitmo temporatura bocatse of the melting caused by condensa-

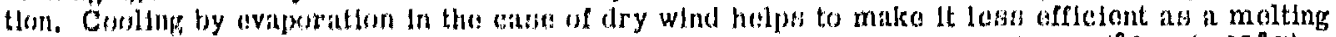

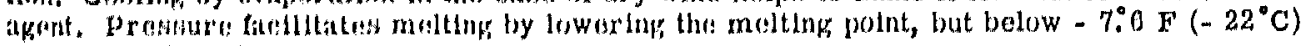

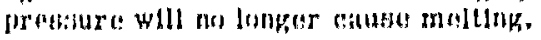

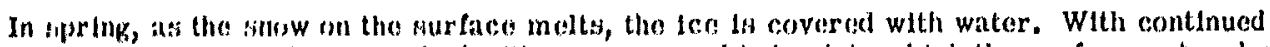
thaw

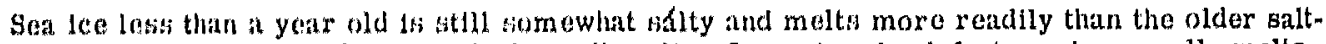
free floes. It also honoycombs extensively as it melts. In spring, land-fast sea lce usually melts flret nenr shore because of the relatively warm water which runs onto it from the land, Wind, waves, currents, and riverss ald break - up and melting, by mechantcal means.

In spring, lake lce "candles." That is, it separates into long pencll-like crystals by melting of intercrystal tllms [BUCHANAN, 1908]. These crystals slide past each other easily, and 1ce two feet thick may not bear the weight of a man. In spring, extreme caution must be used in making alreraft landings on lakes.

Break-up on rivers usiually occurs three or four weeks after the mean alr temperature has risen above $32^{\circ} \mathrm{F}$. Ice on lakes breaks up two or three weeks later, and sea lce may break up about this same time.

Operations on 1ce--Landings on lce are casler to execute than take-offs owing to unevenesses in the ice surface. Planes operating on crusted snow should be careful not to break through the crust in turning.

Frequent measurements of tce thicknegs under and around a landing area should be made in spring, or even dally throughout the period of operation if the lce overlies flowing water. Meas- 
urements can be made by boring a hole through the ice with an auger. The lower part of such a hole is likely to be cone-shaped, so a hook or L-shaped rod should be used to measure thickness of the ice adjacent to the hole [HAYES, 1937]. Measurements made directly in the hole are likely to be in error. The breakup may be preceded by a rapid thinning of the ice, though break-ups can and do occur without any great amount of previous thinning. In high Aretic latitudes lce airdromes could be operated the year around, but any heavily used runway on ice should be given frequent periods of rest to permit recovery from fatigue and sealing of cracks.

Other things to be kept in mind are the notoriously poor depth perception in snow-covered terrain, and the tendency of skis to freeze immediately to ice or snow.

\section{$\underline{\text { References }}$}

BAJKOV, A. D., Unpublished notes and manuscripts.

BARNES, $H_{0}$ T., Ice engineering, Renouf Publishing Company, Montreal, 364 pp., 1928.

BERNIER, J. E., Report on the Dominion of Canada government expedition to the Arctic islands and Hudson Strait on board the D. G. S. Arctic, Ottawa, 1910.

BROWN, R. N. R., The polar regions, Dutton and Co., New York, 245 pp., 1927.

BRUCE, W. S., Polar exploration, Henry Holt and Co., New York, 256 pp., 1911.

BUCHANAN, J. Y., Ice and its natural history, R. Inst. of Great Britain, pp. 1-34, 1908.

BYRD, R. E., Polar exploration by alrcraft, pp. 381-425 in Problems of polar research, Amer. Geogr. Soc., Spec. Pub, 7, 479 pp., 1928.

DEPARTMENT OF NATIONAL DEFENSE, Directorate of Engineering Development, Report on snow and ice, Ottawn, 29 pp., April 1944.

DEVIK, OLA F, Ice formation in lakes and rivers, Geogr. J., v. 103, pp. 193-203, 1944.

DORSEY, N. E., Properties of ordinary water substance, Reinhold Publishing Co., New York, 673 ppo, 1940.

HAYES, RALPH, Safe hauling on lce, photostat of article obtained from U. S. Engineer Office, St. Paul, Minnesota, 1937.

LIGHT, PHILLIP, Analysis of high rates of snow melting, Trans. Amer. Geophys. Union, v. 22, pt. I, pp. 195-205, 1941.

LOW, A. P., Report on the Dominion Government expedition to Hudson Bay and the Arctic Islands on board the D. G. S. Neptune, 1903-1904, Ottawa, 1906.

MATSUYAMA, MOTONORI, On some physical properties of ice, J. Geol., v. 28, pp. 607-631, 1920 .

MOSKATOV, K. A, On the landing of alrplanes upon tce (Translations from Bajkov and from AAF Weather Division), Trans. Arctic Institute, v. 110, pt. 1, pp. 43-54, 1938 a.

MOSKATOV, K. A., Landing on 1ce, Vestnik vozdushvogo flota (Translation by AAF Air Service Command), pp. 40-48, 1938 b.

SELIGMAN, G., Snow structure and sk1 fields, Macmillan and Co., Ltd., New York, 555 pp., 1936.

SMITH, E. H., Ice in the sea, Chapter X, in Physics of the Earth, V, Oceanography, Bull. Nat. Res. Council, no. 85, June, 1932.

TRANSEHE, N. A., The 1ce cover of the Arctic Sea, with a genetic classification of sea ice, pp. 01-123, tn Problems of polar research, Amer. Geogr. Soc., Spec. Pub, no. 7, 479 pp., 1928.

WATKINS, H.G., The British arctic air route expedition, Geogr. J., v. 79, pp. 466-497, 1932.

WILKINS, HUBERT, The flight from Alaska to Spltsbergen, 1928, and the preliminary flights of 1926 and 1927, Geogr. Rev., v. 18, pp. 527-555, $1928 \mathrm{a}$.

WILKKNS, FUBERT, Polar exploration by alrplane, pp. 397-409 in Problems of polar research, Amer, Geogr. Soc, Spec, Pub. no. 7, 479 pp., 1928 b.

WORDIE, J. M., and ROBERTS, B. B., Sea 1ce: Terminology, formation, and movement, The Polar Record, v, 4, pp。126-133, 1944.

zUBOV, No N., The drift of the ice breaker Sedov, Nature, v. 145, pp. $533-539,1940$.

Department of Geology and Mineralogy,

University of Minnesota, Minneapolis, Minnesota

(Manuscript recelved June 3, 1946; presented at the Twenty-Seventh Annual Meeting, Washington, D. C., May 29, 1946; open for formal discussion until July 1,1947.) 